\title{
Peningkatan Penguasaan Konsep Siswa Kelas XI IPA pada Materi Suhu dan Kalor melalui Modeling Instruction
}

\author{
Daniar Pangastiningasih Etikamurni ${ }^{1}$, Sutopo ${ }^{1}$ \\ ${ }^{1}$ Pendidikan Fisika-Universitas Negeri Malang
}

\begin{tabular}{l}
\hline \hline INFO ARTIKEL \\
\hline Riwayat Artikel: \\
Diterima: 07-02-2019 \\
Disetujui: 14-02-2019 \\
\hline
\end{tabular}

\section{Kata kunci:}

mastery of concepts;

heat;

modeling instruction

penguasaan konsep;

kalor;

modeling instruction

\author{
Alamat Korespondensi: \\ Daniar Pangastiningasih Etikamurni \\ Pendidikan Fisika \\ Universitas Negeri Malang \\ Jalan Semarang 5 Malang \\ E-mail: daniar.p.e@gmail.com
}

\begin{abstract}
ABSTRAK
Abstract: This research was aimed to determine the magnitude of the increase in student's conceptual understanding through modeling instruction on temperature and heat material. The subjects of this study were students of SMAN 2 Batu in XI grade which amounted to 65 students. The research design used one group pretest - posttest design which was analyzed quantitatively. Data obtained from the pretest and posttest values are then presented in percentage and statistics. Data was presented through calculation of the average number of students in each indicator, then it was calculated statistically by using the Kolmogorov - Sminorv as normality test, Wilcoxon signed rank for difference test, then followed by $\mathrm{N}$-gain test and effect size to determine the magnitude of increase and influence on variables. The results showed that there was an increase of 0.24 (low category) at the posttest value of students after modeling instruction in the class. The magnitude of the influence of modeling instruction on increasing student's conceptual understanding is equal to 0.69 which falls into the sufficient category.

Abstrak: Penelitian ini bertujuan untuk mengetahui besarnya peningkatan penguasaan konsep siswa melalui modeling instruction pada materi suhu dan kalor. Subjek penelitian ini adalah para siswa SMAN 2 Batu kelas XI yang berjumlah 65 siswa. Design penelitian menggunakan one group pretest - posttest design yang dianalisis secara kuantitatif. Data diperoleh dari nilai pretest dan posttest yang kemudian disajikan dalam bentuk persentase dan statistik. Penyajian data dalam bentuk persentase didapatkan melalui perhitungan rata-rata jumlah siswa pada tiap indikator soal dan penyajian data dalam bentuk statistik diperoleh melalui beberapa pengujian, seperti uji normalitas Kolmogorov-Sminorv, uji beda Wilcoxon signed rank, kemudian dilanjutkan uji $\mathrm{N}$-gain dan effect size untuk mengetahui besarnya peningkatan dan pengaruh terhadap variabel. Hasil penelitian menunjukkan bahwa ada peningkatan sebesar 0.24 (kategori rendah) pada nilai posttest siswa setelah dilakukan modeling instruction di kelas. Besarnya pengaruh modeling instruction terhadap peningkatan penguasan konsep siswa adalah sebesar 0.69 yang masuk ke dalam kategori cukup.
\end{abstract}

Siswa membangun konsep fisika berdasarkan pengalaman kehidupan sehari-hari (Alwan, 2011). Konsep yang telah dibangun terkadang tidak sesuai dengan penjelasan konsep sains. Ketidaksesuaian antara konsep sains dan konsep yang telah dibangun oleh siswa disebut miskonsepsi. Beberapa penelitian menyebutkan bahwa siswa dan calon guru sering mengalami miskonsepsi pada materi fisika (Amalia, Sinaga, Sari, \& Saepuzaman, 2016; Lestari, Rahayu, \& Hikmawati, 2015; Prince, 2011; Setyadi \& Komalasari, 2012; Silung, Kusairi, \& Zulaikah, 2016). Macam-macam miskonsepsi yang sering dialami siswa mengenai konsep suhu dan kalor, antara lain kalor bukan energi; kalor merupaka

n suatu zat; kalor dan suhu adalah hal yang sama (Alwan, 2011); kalor merupakan isolator; kalor merupakan suhu yang berpindah di antara dua benda; titik beku air bukan $0^{\circ} \mathrm{C}$ dan titik didih air tidak tetap (Amalia et al., 2016). Miskonsepsi-miskonsepsi ini tentunya akan memengaruhi penguasaan konsep dan kemampuan pemecahan masalah siswa. Oleh karena itu, dibutuhkan suatu model pembelajaran yang dapat mengatasi permasalahan tersebut. Penelitian yang dilakukan oleh Anderson \& Krathwohl (2001) mengungkapkan bahwa miskonsepsi dapat diperbaiki dengan pembelajaran yang bermakna. Salah satu pembelajaran bermakna yang masih dikembangkan di beberapa negara adalah modeling instruction.

Modeling instruction merupakan model pembelajaran yang dikembangkan oleh Hestenes yang disponsori oleh National Science Foundation (NSF) dari tahun 1989-2005. Modeling instruction merupakan model pembelajaran yang mengekspresikan dan menekankan pembentukan dan pengaplikasian suatu model konseptual dari fenomena fisik sebagai aspek utama untuk mempelajari dan melakukan proses sains (Jackson, Dukerich, \& Hestenes, 2008). Berdasarkan penelitian yang dilakukan oleh 
Jackson Dukerich, \& Hestenes (2008) modeling instruction terdiri atas dua tahapan utama yaitu model development dan model deployment. Tahapan yang pertama adalah model development yang terdiri atas tiga subtahapan. Subtahapan yang pertama adalah prelab discussion yang dimulai dengan demonstrasi dan diskusi kelas dengan menjawab beberapa pertanyaan yang diajukan oleh guru. Hal ini bertujuan agar siswa dapat membentuk pemahaman umum mengenai materi yang akan dipelajari. Subtahapan selanjutnya adalah lab investigation, guru mengajak siswa berdiskusi dalam grup kecil untuk merencanakan dan melakukan eksperimen. Subtahapan terakhir adalah postlab discussion. Pada subtahapan ini, sekelompok siswa mempresentasikan kesimpulan hasil pemodelan persamaan kedepan kelas secara tertulis dan lisan. Tahapan kedua dari modeling instruction adalah model deployment, siswa menerapkan model baru yang mereka temukan ke dalam situasi yang baru untuk memperdalam pemahaman mereka.

Beberapa penelitian yang telah dilakukan menunjukkan bahwa modeling instruction dapat meningkatan penguasaan konsep siswa (Dukerich, 2015; Jackson et al., 2008), dapat meningkatkan upaya belajar siswa dalam mendalami fisika (Brewe et al., 2013), dapat diterapkan pada siswa SMP untuk mempermudah penguasaan konsepnya (La Jumadin, Hidayat, \& Sutopo, 2017) membuat materi lebih jelas dimengerti (Cullen, 2015), memiliki keefektifan dalam mengajarkan fisika (Simeon Chima et al., 2016), dapat meningkatkan kemampuan matematis siswa (Thornton, 2006), memberikan kesempatan kepada siswa dalam mengembangkan model konsep fisika dan mengajak siswa berlatih lebih banyak (Brewe \& Sawtelle, 2018), serta dapat meningkatkan kemampuan pemecahan masalah siswa (Pawl et al., 2009). Materi fisika yang digunakan dalam modeling instruction, antara lain teori kinetik gas (Cullen, 2015; Dukerich, 2015); zat dan energi (Simeon Chima et al., 2016); elastisitas dan energi (Brewe \& Sawtelle, 2018) serta kinematika (Pawl et al., 2009). Namun, sejauh ini belum ditemukan penelitian mengenai modeling instruction yang menggunakan materi suhu dan kalor. Padahal, materi tersebut merupakan bagian penting ketika mempelajari ilmu fisika, sering dijumpai dalam kehidupan sehari-hari (Pathere \& Pradhan, 2010), dan sering terjadi miskonsepsi (Amalia, Sinaga, Sari, \& Saepuzaman, 2016; Lestari, Rahayu, \& Hikmawati, 2015; Prince, 2011; Setyadi \& Komalasari, 2012; Silung, Kusairi, \& Zulaikah, 2016). Miskonsepsi ini berpengaruh pada penguasaan konsep siswa untuk menyelesaikan pemasalahan fisika dengan tepat dan benar (Lestari, Rahayu, \& Hikmawati, 2015).

Pengembangan materi suhu dan kalor dalam penelitian ini terdiri atas empat konsep utama, yaitu suhu dan pemuaian benda, kalor dan pengaruhnya, azas black dan perpindahan kalor. Langkah-langkah dari pelaksanaan modeling instruction materi suhu dan kalor pada penelitian ini dapat dijelaskan sebagai berikut. Kelompok belajar pada penelitian ini terdiri atas 3-4 orang siswa. Instrumen penelitian berupa Lembar Kerja Siswa yang diberikan ke masing-masing kelompok berisi tentang pertanyaanpertanyaan yang dapat membantu siswa memodelkan persamaan pada masing-masing submateri. Lembar Kerja Siswa juga berisi latihan soal dan petunjuk praktikum yang berfungsi untuk memperdalam pemahaman siswa pada tahapan model deployment. Pada tahapan model development - prelab discussion, guru melakukan demonstrasi atau menyajikan video di depan kelas. Siswa diberikan beberapa pertanyaan sederhana dari video atau demonstasi yang telah disajikan untuk membentuk pemahaman umum dari materi yang akan diajarkan. Kemudian, pada subtahapan lab investigation, siswa diminta untuk mengerjakan Lembar Kerja Siswa secara berkelompok. Pada subtahapan ini, guru berperan sebagai fasilitator yang membantu siswa dalam mengerjakan Lembar Kerja Siswa. Tahapan selanjutnya, postlab discussion, guru meminta salah satu kelompok siswa untuk mempresentasikan hasil diskusi mereka ke depan kelas dan guru membantu siswa dalam membentuk model yang benar. Di akhir pertemuan materi suhu dan kalor, siswa diminta mengerjakan tes penguasaan konsep untuk mengukur besar pengaruh modeling instruction terhadap penguasaan konsep siswa. Artikel ini ditulis bertujuan untuk mengetahui besarnya peningkatan penguasaan konsep siswa pada materi suhu dan kalor setelah diberikan perlakuan berupa modeling instruction.

\section{METODE}

Penelitian ini dilaksanakan di SMAN 02 Batu. Subjek penelitian adalah siswa kelas XI tahun ajaran 2018 - 2019 yang berjumlah 65 siswa. Metode penelitian ini menggunakan one group pretest-posttest design, yang memiliki tujuan untuk mengetahui pengaruh dari perlakuan yang diberikan terhadap hasil akhir pengukuran variabel (Johnson \& Christensen, 2014). Siswa diberikan pretest untuk mengidentifikasi penguasaan konsep siswa mengenai materi suhu dan kalor sebelum diberikan perlakuan berupa modeling instruction. Setelah modeling instruction diterapkan ke siswa, peneliti mengukur kembali penguasaan konsep siswa dengan memberikan posttest. Instrumen dari penelitian ini menggunakan 20 soal penguasaan konsep berupa pilihan ganda yang dikelompokkan dalam sembilan indikator. Sebaran soal pada masing-masing indikator pencapaian kompetensi dapat dilihat pada Tabel 1. Karakteristik yang dimiliki instrumen ini, meliputi nilai reliabilitas soal sebesar 0.66; daya beda soal dalam rentang $0.03-0.967$ dengan rata - rata 0.571; tingkat kesukaran soal dalam rentang $0.07-0.76$ dengan rata - rata 0.520 .

Data kuantitatif diperoleh melalui pretest dan posttest yang akan disajikan dalam bentuk persentase dan statistik. Penyajian data persentase terbagi menjadi tiga kategori di tiap indikator, yaitu jawaban benar, jawaban salah, dan tidak menjawab. Hal ini bertujuan untuk membandingkan besarnya perubahan persentase jumlah siswa ketika pretest dan posttest pada masingmasing kategori. Perhitungan persentase per indikator menggunakan rata-rata jumlah siswa pada masing-masing indikator.

Penyajian data statistik bertujuan untuk mengetahui besarnya peningkatan dan efek dari modeling instruction pada penguasaan konsep secara menyeluruh. Penyajian data ini menggunakan pengujian statistik yang meliputi uji normalitas sebagai uji prasyarat, uji beda Wilcoxon signed rank yang dilanjutkan dengan uji $N$ - gain dan effect size. 
Tabel 1. Sebaran Soal Pada Masing-Masing Indikator Pencapaian Kompetensi

\begin{tabular}{clc}
\hline No & \multicolumn{1}{c}{ Indikator Pencapaian Kompetensi } & No Soal \\
\hline 1 & Siswa dapat menjelaskan kontak termal dan kesetimbangan termal & 1,2 \\
2 & Siswa dapat menjelaskan konsep pemuaian pada benda & $3,4,5,6,18$ \\
3 & Siswa dapat menjelaskan konsep kalor dan hubungannya dengan suhu benda & $7,8,9$ \\
4 & Siswa dapat menerapkan persamaan kalor terhadap perubahan suhu & 10 \\
5 & Siswa dapat menerapkan persamaan azas Black & 11,19 \\
6 & Siswa dapat menerapkan persamaan kalor terhadap perubahan wujud benda & 12,20 \\
7 & Siswa dapat mengidentifikasi perpindahan kalor secara konduksi, konveksi dan radiasi & 13,14 \\
8 & Siswa dapat menjelaskan factor-faktor yang memengaruhi laju kalor secara konduksi, & 15,17 \\
& konveksi, dan radiasi & 16 \\
9 & Siswa dapat menerapkan persamaan laju kalor secara konduksi dan radiasi & \\
\hline
\end{tabular}

\section{HASIL}

Penguasaan konsep yang diukur pada penelitian ini dibatasi pada sembilan indikator pencapaian kompetensi. Persentase jawaban dari 65 siswa pada masing-masing indikator pencapaian kompetensi dapat dilihat pada Tabel 2.

Tabel 2. Persentase Jumlah Siswa Pada Masing-masing Indikator Pencapaian Kompetensi

\begin{tabular}{|c|c|c|c|c|c|c|c|}
\hline \multirow[b]{2}{*}{ No } & \multirow[b]{2}{*}{ Indikator Pencapaian Kompetensi } & \multicolumn{3}{|c|}{ PRETEST } & \multicolumn{3}{|c|}{ POSTTEST } \\
\hline & & Benar & Salah & $\begin{array}{c}\text { Tidak } \\
\text { Menjawab }\end{array}$ & Benar & Salah & $\begin{array}{c}\text { Tidak } \\
\text { Menjawab }\end{array}$ \\
\hline 1 & $\begin{array}{l}\text { Siswa dapat menjelaskan kontak termal dan } \\
\text { kesetimbangan termal }\end{array}$ & $38 \%$ & $51 \%$ & $11 \%$ & $45 \%$ & $51 \%$ & $4 \%$ \\
\hline 2 & Siswa dapat menjelaskan konsep pemuaian pada benda & $19 \%$ & $66 \%$ & $15 \%$ & $21 \%$ & $73 \%$ & $6 \%$ \\
\hline 3 & $\begin{array}{l}\text { Siswa dapat menjelaskan konsep kalor dan hubungannya } \\
\text { dengan suhu benda }\end{array}$ & $19 \%$ & $70 \%$ & $12 \%$ & $40 \%$ & $53 \%$ & $7 \%$ \\
\hline 4 & $\begin{array}{l}\text { Siswa dapat menerapkan persamaan kalor terhadap } \\
\text { perubahan suhu }\end{array}$ & $16 \%$ & $65 \%$ & $19 \%$ & $34 \%$ & $44 \%$ & $22 \%$ \\
\hline 5 & Siswa dapat menerapkan persamaan azas Black & $21 \%$ & $56 \%$ & $24 \%$ & $19 \%$ & $75 \%$ & $6 \%$ \\
\hline 6 & $\begin{array}{l}\text { Siswa dapat menerapkan persamaan kalor terhadap } \\
\text { perubahan wujud benda }\end{array}$ & $15 \%$ & $63 \%$ & $22 \%$ & $35 \%$ & $59 \%$ & $7 \%$ \\
\hline 7 & $\begin{array}{l}\text { Siswa dapat mengidentifikasi perpindahan kalor secara } \\
\text { konduksi, konveksi dan radiasi }\end{array}$ & $24 \%$ & $57 \%$ & $18 \%$ & $32 \%$ & $54 \%$ & $14 \%$ \\
\hline 8 & $\begin{array}{l}\text { Siswa dapat menjelaskan factor-faktor yang } \\
\text { memengaruhi laju kalor secara konduksi, konveksi dan } \\
\text { radiasi }\end{array}$ & $26 \%$ & $50 \%$ & $24 \%$ & $21 \%$ & $63 \%$ & $16 \%$ \\
\hline 9 & $\begin{array}{l}\text { Siswa dapat menerapkan persamaan laju kalor secara } \\
\text { konduksi dan radiasi }\end{array}$ & $13 \%$ & $62 \%$ & $25 \%$ & $18 \%$ & $72 \%$ & $10 \%$ \\
\hline
\end{tabular}

Berdasarkan Tabel 2, dapat diketahui bahwa beberapa indikator pencapaian kompetensi mengalami peningkatan persentase pada kategori jawaban benar, kecuali pada indikator nomor 5 dan 8 . Peningkatan persentase juga dialami pada kategori jawaban salah terutama pada indikator nomor 2, 5, 8, dan 9 .

Data pretest dan posttest dalam penelitian ini dilakukan beberapa pengujian, meliputi uji normalitas sebagai uji prasyarat, uji beda menggunakan uji Wilcoxon signed rank; uji $\mathrm{N}$-gain dan Effect size untuk mengetahui seberapa besar pengaruh modeling instruction terhadap nilai posttest siswa. Analisis statistik untuk penguasaan konsep siswa pada materi suhu dan kalor dilakukan dengan menggunakan bantuan software IBM SPSS Statistics 24 dan Microsoft Excel dapat dilihat pada Tabel 3. 
Tabel 3. Deskripsi Hasil Analisis Skor Penguasaan Konsep

\begin{tabular}{ccc}
\hline Unsur-unsur Statistik & Pretest & Posttest \\
\hline$N$ & 65 & 65 \\
$\overline{\boldsymbol{X}}$ & 61.5385 & 70.7692 \\
$X_{\max }$ & 40 & 45 \\
$X_{\min }$ & 85 & 100 \\
$S D$ & 11.00153 & 9.15282 \\
\hline
\end{tabular}

Besarnya uji normalitas yang telah dilakukan menunjukkan angka 0.001 yang menunjukkan bahwa data tidak terdistribusi normal. Uji beda dilakukan menggunakan uji Wilcoxon yang menghasilkan nilai signifikansinya sebesar 0.000 . Kemudian, data pretest dan posttest diuji menggunakan $N$ - Gain untuk mengetahui besarnya peningkatan skor penguasaan konsep. Pada Uji $N$ - Gain menunjukkan bahwa besarnya peningkatan skor pretest dan posttest sebesar 0.24 yang memiliki kategori rendah (Hake, 1999). Sedangkan besarnya efek modeling instruction dapat dihitung menggunakan uji Effect Size yang menunjukkan angka 0.69 atau berkategori cukup (Cohen et al., 2007).

\section{PEMBAHASAN}

Berdasarkan Tabel 3, dengan membandingkan persentase pretest dan posttest pada masing-masing kategori, diketahui bahwa terjadi penurunan persentase jawaban benar pada indikator nomor 2,5,8, dan 9 dan peningkatan persentase jawaban salah pada indikator nomor 5 dan 8. Hal ini disebabkan ketidaktepatan siswa dalam memilih jawaban yang dapat mengindikasikan terjadinya miskonsepsi. Detail miskonsepsi yang dimiliki siswa pada keempat indikator ini akan dibahas pada penelitian ini.

Indikator 2 menyatakan bahwa siswa dapat menjelaskan konsep pemuaian pada benda. Pada indikator tersebut terjadi peningkatan persentase kategori jawaban salah yaitu $66 \%$ menjadi $73 \%$. Hal ini dikarenakan beberapa siswa kurang memahami mengenai konsep pemuaian pada benda. Beberapa siswa berpendapat bahwa koefisien muai suatu zat cair tidak memengaruhi keakurasian termometer; siswa lain juga berpendapat bahwa raksa merupakan satu-satunya zat cair yang selalu digunakan sebagai pengisi termometer; bola berongga dan bola berisi zat cair lebih cepat memuai daripada bola pejal jika dipanaskan dalam waktu yang sama; cincin emas akan berkurang atau bertambah ketebalannya ketika dipanaskan.

Siswa dapat menerapkan persamaan azas Black merupakan pernyataan dari indikator 5. Pada indikator tersebut terjadi peningkatan persentase kategori jawaban salah sebesar 9\%. Kemudian, pada kategori jawaban benar mengalami penurunan sebesar $1 \%$. Hal tersebut disebabkan karena siswa mengalami kesulitan dalam menerapkan persamaan azas Black dan kurang memahami mengenai proses perpindahan kalor. Beberapa siswa tidak dapat menghitung besarnya perubahan suhu pada benda yang melepas kalor dan benda yang menerima kalor. Siswa berpendapat bahwa perubahan suhu dihitung dari selisih antara suhu benda yang melepaskan kalor dengan suhu benda yang menerima kalor, tanpa memperhitungkan suhu campuran kedua benda. Miskonsepsi yang dimiliki siswa pada indikator ini, meliputi perpindahan suhu dapat terjadi pada benda yang berbeda suhu dan benda bersuhu rendah mengalami pelepasan dan penerimaan energi. Hasil penelitian yang dilakukan oleh Amalia, Sinaga, Sari, \& Saepuzaman (2016) menyebutkan bahwa beberapa siswa mengalami miskonsepsi tentang suhu dan kalor antara lain : suhu dapat berpindah dari benda satu ke benda lainnya; suhu campuran dari dua benda yang berbeda suhu didapatkan dengan menambahkan kedua suhu awal; kalor berpindah dari suhu yang lebih dingin ke suhu yang lebih rendah.

Selanjutnya, pada indikator 8 yang menyataakan bahwa siswa dapat menjelaskan factor-faktor yang memengaruhi laju kalor secara konduksi, konveksi dan radiasi. Pada indikator ini terjadi peningkatan kesalahan jawaban sebesar $13 \%$, kemudian pada kategori jawaban benar terjadi penurunan sebesar 5\%. Kesalahan ini disebabkan siswa memiliki konsep bahwa batang logam yang disusun seri dan paralel memiliki laju perpindahan kalor yang sama. Padahal menurut persamaan laju kalor konduksi, laju kalor berbanding terbalik dengan panjang batang. Konsep lain yang dimiliki siswa adalah laju kalor dipengaruhi oleh massa jenis benda. Indikator 9 yang menyatakan siswa dapat menerapkan persamaan laju kalor konduksi dan radiasi mengalami peningkatan persentase kategori jawaban salah sebesar 10\%. Kesalahan siswa dalam menjawab soal pada indikator 9 disebabkan karena siswa belum dapat menerapkan persamaan laju kalor secara radiasi. Beberapa siswa tidak mengingat persamaan laju kalor radiasi dan tidak meengubah satuan suhu menjadi Kelvin.

Berdasarkan kesulitan siswa yang telah dipaparkan sebelumnya, terdapat beberapa faktor yang menjadi penyebab siswa mengalami miskonsepsi dan tidak menguasai konsep pada materi ini, antara lain terjadinya tumpang tindih pengetahuan awal siswa dengan konsep suhu dan kalor (Rimadani, Parno, \& Diantoro, 2016); siswa menjawab berdasarkan konsepsi alternatifnya (Alwan, 2011; Aryani, Handayanto, \& Wisodo, 2016); siswa mengalami kesulitan dalam menghubungkan konsep dengan konsep sehari-hari (Chu et al., 2012). Walaupun demikian, secara keseluruhan, penguasaan konsep siswa mengalami perubahan positif setelah dilakukan modeling instruction di dalam kelas. Hal ini dapat dilihat dari Tabel 3 yang menunjukkan hasil pengujian statistik data pretest dan posttest. Skor rata-rata $(\bar{X})$ penguasaan konsep siswa mengalami peningkatan dari 61.53 menjadi 70.77. Besarnya peningkatan ini telah dihitung menggunakan uji $N$-Gain dengan skor 0.24 dengan kategori rendah. Sementara itu, efek dari modeling instruction terhadap penguasaan konsep dihitung dengan menggunakan effect size yang menghasilkan skor 0.69 dengan kategori cukup. Dengan demikian, dapat disimpulkan bahwa tahapan pembelajaran modeling instruction yang telah diterapkan di kelas dapat meningkatkan penguasan konsep siswa. 


\section{SIMPULAN}

Penerapan modeling instruction di kelas dapat meningkatkan penguasaan konsep siswa pada materi suhu dan kalor dengan skor $\mathrm{N}$-gain sebesar 0.24 (kategori rendah) dan nilai effect size sebesar 0.69 (kategori cukup). Peningkatan ini juga dapat dilihat dari besarnya persentase siswa dalam menjawab soal posttest dengan jawaban benar mengalami peningkatan jika dibandingkan ketika pretest. Namun, terdapat dua submateri yang memiliki peningkatan persentase pada jawaban salah, yaitu pemuaian dan perpindahan kalor. Hal ini disebabkan karena siswa mengalami kesulitan dalam menerapkan persamaan kedua submateri tersebut ke dalam soal.

Modeling instruction terbukti cukup efektif dalam meningkatkan penguasaan konsep siswa. Berkaitan dengan hal tersebut, diharapkan kepada para guru dapat menerapkan modeling instruction pada materi fisika lainnya agar siswa tidak mengalami miskonsepsi mengenai konsep fisika. Penggunaan media pembelajaran yang mengaitkan dengan fenomena kehidupan sehari-hari dapat menarik minat siswa ketika belajar fisika. Pemberian latihan soal yang lebih banyak pada tahapan model development perlu ditekankan untuk memperkuat konsep siswa yang telah dibentuk pada tahapan model development.

\section{DAFTAR RUJUKAN}

Alwan, A. A. (2011). Misconception of Heat and Temperature Among Physics Students. Procedia - Social and Behavioral Sciences, 12, 600-614. DOI: 10.1016/j.sbspro.2011.02.074

Amalia, R., Sinaga, P., Sari, I. M., \& Saepuzaman, D. (2016). Identifikasi Miskonsepsi Siswa SMA di Kota Bandung pada Konsep Suhu dan Kalor. Prosiding Semnas IPA Pascasarjana UM, 1.

Anderson, L. W., \& Krathwohl, D. R. (2001). A Taxonomy for Learning, Teaching and Assesing (Abridged). New York: Longman.

Aryani, P. A. S. N., Handayanto, S. K., \& Wisodo, H. (2016). Penguasaan Konsep Siswa SMA pada Materi Suhu dan Kalor. Prosiding Semnas IPA Pascasarjana UM, 1.

Brewe, E., \& Sawtelle, V. (2018). Modeling Instruction for University Physics: Examining the Theory in Practice. European Physics Journal. https://doi.org/10.1088/1361-6404/aac236

Brewe, E., Traxler, A., Garza, J. de la, \& Kramer, L. H. (2013). Extending Positive Class Results Across Multiple Instructors and Multiple Classes of Modeling Instruction. Physical Review Special Topic - Physics Education Research, 9. https://doi.org/10.1103/PhysRevSTPER.9.020116

Chu, H. E., Treagust, D. F., Yeo, S., \& Zadnik, M. (2012). Evaluation of Student's Understanding of Thermal Concepts in Everyday Contexts. International Journal of Science Education, 34(10), 1509-1534. https://doi.org/10.1080/09500693.2012.657714

Cohen, L., Manion, L., \& Morrison, K. (2007). Research Methods in Education (6th edition). New York: Routledge.

Cullen, D. M. (2015). Modeling Instruction: A Learning Progression That Makes High School Chemistry More Coherent to Students. Journal of Chemical Education, 92(8), 1269-1272. https://doi.org/10.1021/acs.jchemed.5b00544

Dukerich, L. (2015). Applying Modeling Instruction to High School Chemistry to Improve Students' Conceptual Understanding. Journal of Chemical Education, 92(8), 1315-1319. https://doi.org/10.1021/ed500909w

Jackson, J., Dukerich, L., \& Hestenes, D. (2008). Modeling Instruction: An Effective Model for Science Education. Science Educator, 17(1), 10-17.

Johnson, R. B., \& Christensen, L. (2014). Educational Research (5th Edition). USA: SAGE Publication.

Kartal, T., Öztürk, N., \& Yalvaç, H. G. (2011). Misconceptions of Science Teacher Candidates about Heat and Temperature., Procedia - Social and Behavioral Sciences, 15, 2758-2763. https://doi.org/10.1016/j.sbspro.2011.04.184

La Jumadin, Hidayat, A., \& Sutopo. (2017). Perlunya Pembelajaran Modeling Instruction pada Materi Gelombang. Jurnal Pendidikan Teori, Penelitian, dan Pengembangan, 2(3), 325-330.

Lestari, P. A. S., Rahayu, S., \& Hikmawati. (2015). Profil Miskonsepsi Siswa Kelas X SMKN 4 Mataram pada Materi Pokok Suhu dan Kalor dan Perpindahan Kalor. Jurnal Pendidikan Fisika dan Teknologi, 1(3), 146-153. http://dx.doi.org/10.29303/jpft.v1i3.251

Pathere, S. R., \& Pradhan, H. C. (2010). Student's Misconception about Heat Transfer Mechanisms and Elementary Kinetic Theory. Institute of Physics Publishing.

Pawl, A., Barrantes, A., \& Pritchard, D. E. (2009). Modeling Applied to Problem Solving. American Institute Physics, 1179(51). https://doi.org/10.1063/1.3266752

Prince, M. J. (2011). The Use of Inquiry-Based Activities to Repair Student Misconceptions Related to Heat, Energy and Temperature. American Society for Engineering Education.

Rimadani, E., Parno, \& Diantoro, M. (2016). Penguasaan Konsep dan Kemampuan Pemecahan Masalah Siswa SMA pada Materi Suhu dan Kalor. Prosiding Semnas IPA Pascasarjana UM, 1.

Setyadi, K. E., \& Komalasari, A. (2012). Miskonsepsi tentang Suhu dan Kalor pada Siswa Kelas 1 di SMA Muhammadiyah Purworejo Jawa Tengah. Berkala Fisika Indonesia: Jurnal Ilmiah Fisika, Pembelajaran dan Aplikasinya, 4(1 \& 2), 4649. 
Silung, S. N. W., Kusairi, S., \& Zulaikah, S. (2016). Diagnosis Miskonsepsi Siswa SMA di Kota Malang pada Konsep Suhu dan Kalor menggunakan Three Tier Test. Jurnal Pendidikan Fisika dan Teknologi, 2(3), 95-105. http://dx.doi.org/10.29303/jpft.v2i3.295

Simeon Chima, N., Mumuni, A. A. O., \& Dike, J. W. (2016). Effectiveness of Modeling Instruction and Secondary Students' Performance in Physics in Rivers State. International Journal of Education and Evaluation, 2(4), 27-36.

Thornton, R. K. (2006). Measuring and Improving Student Mathematical Skills for Modeling. Proceedings GIREP Conference. 